\title{
The Decision Support System in Choosing The Quality of Charcoal Briquettes from Coconut Shell to Improve The Quality and Maximised by The Method of Analytical Hierarchy Process (the case study in Padang pariaman)
}

\author{
Muhammad Ilham A Siregar ${ }^{1}$, Wahyuni Yahyan ${ }^{2}$, Danyl Mallisza ${ }^{3}$ \\ ${ }^{1,2,3}$ Sistem Informasi/ Program Studi Diploma III MIK Universitas Ekasakti Padang \\ Veteran Dalam Street 26b Padang, telp. : (0751) 28859 fax.: (0751) 32694 \\ e-mail: ${ }^{1}$ bithong234@gmail.com, ${ }^{2}$ wahyuniyahyan150889@gmail.com, \\ 3anylmallisza2483@gmail.com
}

\begin{abstract}
The regency of Padang Pariaman is one of the centres of the plantation to the plant oil in the region of West Sumatra. Many find various types of plant oil that spread in every area. Decision-Making system (DSS) should be able to understand the problems that exist that are the basis for the decision (the decision Maker) to determine the priority of the selection and determine the type of charcoal coconut charcoal quality to be used as briquettes. This study obtained the top Level (Goal) is the selection of Charcoal Material priorities approved as the purpose of this study. The Level of the heart (the Criterion) in the hierarchy that shows the criteria that the Color of the Skin, Coconut Fiber, Coconut Shell, water Content, Coconut Meat. The lowest Level (Alternatives) in the hierarchy that shows the alternate choice of the Type of Coconut, which is helpful as briquettes, that Old Coconut, Coconut Koreang, Coconut Mudang, Young Coconut. Of the highest rank possessed by the alternatives is the type of Old Coconuts (0.600) and second by the kind of Coconut Koreang 2 (0.242), the Type of Coconut 3 Coconut Mudang (0.113) and ranking low is a Young Coconut (0.046) as a material consideration in the manufacture of charcoal quality then in the analysis, the priority is the "Old Palm"
\end{abstract}

Keywords: Coconut, Briquettes, Shell, DSS, AHP

\section{Introduction}

Indonesia is known for having 3,712 million hectares of coconut Plantation Island in the world, most of them are the plantations are owned by the citizen (96.6\%), while the rest owned by the nation $(0.7 \%)$, and the private one is about $(2.7 \%)$. Coconut plants are multipurpose plants and well known in Indonesian society as well. Coconut plants have so many benefits for human life consists of fibre, shell, meat (fruit), leaves and coconut water. Padang Pariaman Regency is one of the plantation centres for coconut plants in the West Sumatra, where there are so many kinds of coconut plants spread of these regions[1 ]

Residents widely use coconut plants in the Padang Pariaman area start with meat (fruit), fibres, shells and others. The types of coconuts that researchers have done in Padang Pariaman such as old coconut plants, Koreang coconut, mudang coconut, mudo coconut /young coconut. Coconut shell charcoal is included in the category of hardwood and contains higher levels of lignin (woody substances) and levels of cellulose (organic compounds) with a water content of about six to nine per cent (calculated based on dry weight) and is mainly composed of lignin, cellulose and hemicellulose[2]

The community in Padang Pariaman utilise coconut shell as an alternative to be used as a fuel substitute for kerosene, while charcoal from coconut shell can process into briquettes. Processed products from coconut shell charcoal which used as briquettes have some advantages 
such as non-toxic, smokeless, go green energy, burning time spent, and as an alternative to the gas stove[3]

For the type of charcoal which are not in good quality, and not all kinds of coconut can use in making the briquette charcoal. The type of charcoal which used for briquettes must have good/stable heat quality. Many losses have happened to producers in charcoal because the coconut shell type is included in the unfavourable category if it included in that category. Otherwise, the production of charcoal to be used as briquettes is not suitable for marketing [4]

To determine the selection of coconut shell charcoal for briquettes, researchers used the Decision Support System (DSS) method with the Analytical Hierarchy Process (AHP). If in making decision not based on the precise data and information, those only based on mere assumptions, the decision cannot wholly resolve existing problems and will lead to new difficulties instead, therefore, researchers tried to conduct research by using AHP, in making the decision to choose coconut shell charcoal that will be used as briquettes and finally, it will be more systematic than scientific disciplines in the field of computer science[5]

Decision Support system (Decision Support System/ DSS) provides ease in taking the decision that can help the problems based on multiple criteria and alternatives that have been set by the expert. Decision Support system (DSS) is a part of computer-based information systems include knowledge-based systems or knowledge management which are used to support decision making in an organisation or company [6]

The method of AHP (Analytical Hierarchy Process) is widely used to study both individuals and groups in decision-making, experts who work to solve a very complex problem, Ivan Pogarčić, et al. (2008). The method of Analytical Hierarchy Process (AHP) was first developed in the 1970s by Thomas L. Saaty, a mathematics expert from the college of the University of Pittsburgh. AHP is a method that has popularly used in retrieval systems/ decision support, which involves a subjective assessment of the decision-maker/ expert.

Based on the description of the existing problems above, the researcher interested to do research Decision Support System (DSS) In the Choose Quality Briquette From Coconut Shell Charcoal To Improve the Quality and Maximum Results With AHP Method (Case Study in Padang Pariaman).

The results of this study can ascertain the type of oil that is there in Padang Pariaman worth used for the manufacture of briquettes, the formula of AHP and input from experts draw into the guidelines to calculate the type of oil that is better and can be applied with DSS using the AHP Method[7]

\section{Research Methods}

The research method can be grouped based on, objectives, and the level of natural (natural setting) of the object under study. Based on the goals, the research methods can be classified into basic research, applied research and research \& development. The Decision-Making System (SPK) must be able to understand the existing problems which are the basis for the decision-maker (Decision Maker) to determine the priority of selection and determine the type of quality coconut shell charcoal to be used as briquettes.

The diversity of criteria for decision-makers is more than one, which will lead to complexity in decision making; the Analytical Hierarchy Process (AHP) method can provide solutions to these complex problems. Sources of data that researchers use in research was by using primary data that is data collected directly by researchers. This data is the primary data in this study, usually in the form of direct observation with relevant parties and questionnaires filled in instantly by experts - primary data obtained from various reference journals, books and scientific articles [8] 


\subsection{Framework}

1. Literature Study, in the initial stage of this study, collecting supporting references in the form of journals, research articles and the book Decision Support System for SPK, Coconut Plants, and AHP (Analytical Hierarchy Process) as the beginning of this research.

2. Data Collection, At this stage, the researchers collected data in Padang Pariaman on PT Roda Banting which produces coconut briquettes which located in the Pauh region as well as the community in the Garinging River area where producing coconut charcoal. The data the researchers collected included primary data and secondary data. Data collection method used is observation by observing directly.

3. Questionnaire At this stage, the researchers gave questionnaire data to the experts for decision making to get suitable coconut species.

4. Problem Identification At this stage, after the data fulfilled, an appropriate set of data is obtained to be carried out in the process of modelling the hierarchy and the algorithm, so that information on indicators with specific criteria obtain.

5. Designing the Hierarchy Model at this stage the data analysis is done by creating a model in the form of a data hierarchy (decomposition) to help solve problems into its elements to describe the level of existing problems. The design of this model can produce accurate analysis results.

6. Data Processing with AHP At this stage, the data calculation process is carried out with the MS application. Excel uses a formula that refers to the AHP method, with the first step to assess the relationship of elements at each level of the hierarchy to determine the priority of the features and then the results presented in the form of a matrix.

7. Selection of Alternative Solutions, at this stage the desired output is obtained in the way of several alternative solutions, and then the analysis is carried out to determine whether the results obtained are under the facts or previous hypotheses.

8. Evaluation and Trial, at this stage an assessment and trial are carried out to find out whether the new system developed is effective and efficient in achieving the objectives in choosing the type of coconut for quality charcoal which will later make with good quality briquettes[9]

\section{Result and Discussion}

For the results of the end of this study will be in the form of a Decision Support System (SPK) with the AHP Method for the type of coconut that is suitable for use in making briquettes so that the results are more optimal. AHP Method Calculation ${ }^{10}$.

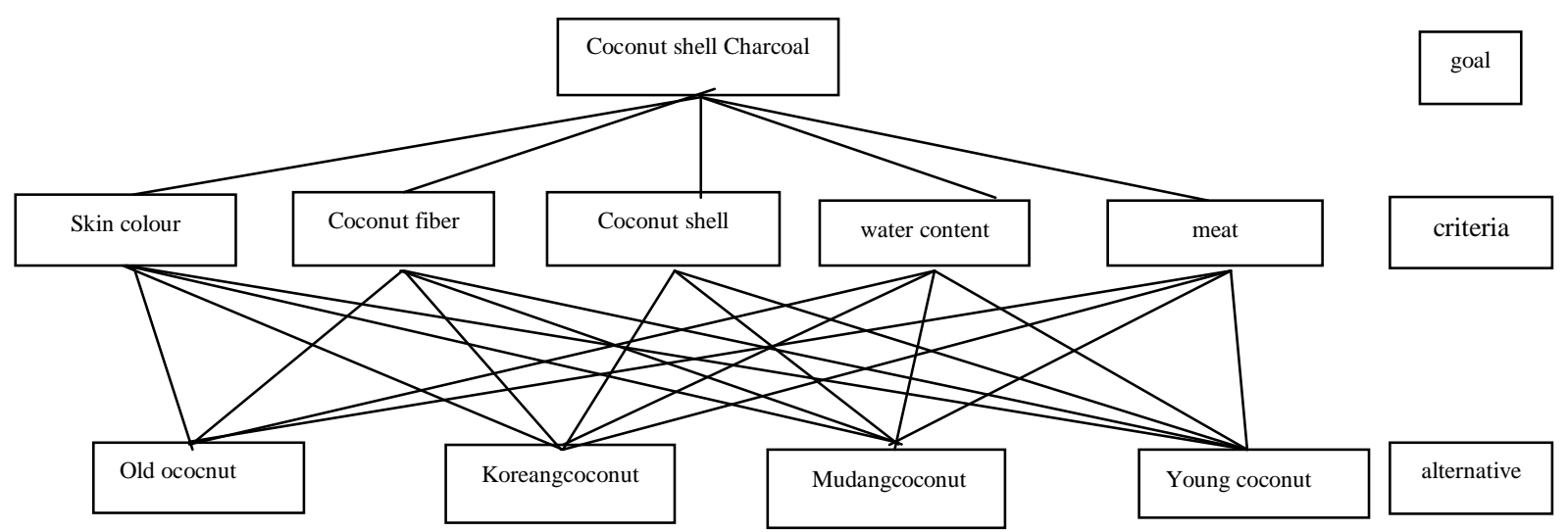

Figure 2. Determination of Coconut Charcoal 
In figure 2, there are three levels, which are: The top-level (Goal), namely the selection of priority Charcoal Materials that approved as the objectives of this study. The middle level (Criteria) in this hierarchy is showing criteria, namely Skin Color, Coconut Fiber, Coconut Shell, Water Content, Coconut Meat. The lowest level (Alternative) in this hierarchy is explaining choices of right types of Coconut used as briquettes, namely Old Coconut, Koreang Coconut, Mudang Coconut, Young Coconut.

\subsection{System requirements analysis}

Based on data collected from the research site, the criteria in shell charcoal for briquettes:

1. Skin Color

2. Coconut Fiber

3. Coconut Shell

4. Coconut water content

5. Coconut Meat

Based on data collected from the research field, alternatives in charcoal for briquette:

1. Coconut 1: Old Coconut

2. Coconut 2: Koreang Coconut

3. Coconut 3: Mudang Coconut

4. Coconut 4: Young Coconut

In analysing the calculation of AHP (Analytical Hierarchy Process), the researcher used the data from CV Roda Banting and for the analysis of this calculation; the writer takes four types of coconut in Padang Pariaman. Based on the data that has obtained, the criteria in determining the title of the study are as follows:
1. Skin Color (SC)
2. Coconut Fiber $(\mathrm{CF})$
3. Coconut Shell (SC)
4. Coconut Water Content (CWC)
5. Coconut Meat (CM)

Table 1. Scales of Comparison Assessment Criteria

\begin{tabular}{|c|c|c|c|c|c|}
\hline Criteria & CM & CWC & CS & CF & SC \\
\hline $\mathrm{CM}$ & 1 & 2 & 3 & 4 & 5 \\
\hline $\mathrm{CWC}$ & $1 / 2$ & 1 & 2 & 3 & 4 \\
\hline $\mathrm{CF}$ & $1 / 3$ & $1 / 2$ & 1 & 2 & 3 \\
\hline $\mathrm{CS}$ & $1 / 4$ & $1 / 3$ & $1 / 2$ & 1 & 2 \\
\hline $\mathrm{SC}$ & $1 / 5$ & $1 / 4$ & $1 / 3$ & $1 / 2$ & 1 \\
\hline
\end{tabular}

\subsection{Finding Eigen Vectors}

Find a valid Eigenvector. It is necessary to repeat the Eigenvector search to obtain the value of Eigenvector 1 and 2. If the value between Eigenvector 1 and 2 has a small difference, then the Eigenvector value is declared valid.

1. Eigenvector 1 (iteration 1)

Table 2 Finding the Vector Eigen 1

\begin{tabular}{|c|c|c|c|c|c|}
\hline & CM & CWC & CS & CF & SC \\
\hline CM & A & B & C & D & F \\
\hline CWS & G & H & I & J & K \\
\hline CS & L & M & N & O & P \\
\hline CF & Q & R & S & T & U \\
\hline SC & V & W & X & Y & Z \\
\hline
\end{tabular}

eISSN: 2477-3255, pISSN: 2086-4884

https://doi.org/10.31849/digitalzone.v10i2. 3274 


$$
\begin{aligned}
& A^{\prime}=\left(A^{*} A\right)+(B * G)+\left(C^{*} L\right)+(D * Q)+(V * F) \\
& A^{`}=(1 \times 1)+(0,5 \times 2)+(0,333 \times 3)+(0,25 \times 4)+(0,2 \times 5) \\
& A^{`}=1+1+0,99+1+1 \\
& A^{`}=4,99=5 \text { and so on }
\end{aligned}
$$

\subsection{Normalization}

Looking for the result of normalisation values by adding up all the benefits in each row so that the total amount of rows obtained, then adding the total of each row then dividing the full rows by the total number of rows to get the normalisation value.

Table 3 Vector Eigen values 1 Normalized Results

\begin{tabular}{|c|c|c|c|c|c|c|c|}
\hline & CM & CWC & CS & CF & SC & $\begin{array}{l}\text { Result of } \\
\text { Eigen 1 }\end{array}$ & $\begin{array}{l}\text { Result of } \\
\text { Normalisation }\end{array}$ \\
\hline CM & 4,999 & 8,082 & 13,665 & 22,500 & 35,000 & 84,246 & 0,419 \\
\hline CWC & 3,216 & 4,999 & 8,332 & 14,000 & 22,500 & 53,047 & 0,264 \\
\hline CS & 2,016 & 3,082 & 4,999 & 8,332 & 13,665 & 32,093 & 0,160 \\
\hline EF & 1,233 & 1,916 & 3,082 & 4,999 & 8,082 & 19,312 & 0,096 \\
\hline SC & 0,761 & 1,233 & 2,016 & 3,216 & 4,999 & 12,225 & 0,061 \\
\hline \multicolumn{7}{|c|}{ Total } & \\
\hline
\end{tabular}

\subsection{Calculation of Consistency Ratio}

In the AHP Method, a ratio of consistency needed in each Eigenvector result. For each criterion value. Because of the higher the value of the consistency ratio, the more inconsistent the results of the assessment. Tolerate value of 0.1 ; if the value of the consistency ratio exceeds the provisions, the value must improve.

a. Calculation of the consistency of index (CI)

The next stage is finding the value of CI

$$
\begin{aligned}
\mathrm{CI} & =\frac{\lambda \max -\mathrm{n}}{\mathrm{n}-1} \\
& =\frac{5.06-5}{5-1} \\
& =0.018
\end{aligned}
$$

b. Determine the Consistency of the Ratio

Determine the consistency ratio is by dividing the results of the consistency index by a random index value.

$$
\begin{aligned}
\mathrm{CR} & =\frac{\mathrm{CI}}{\mathrm{RI}} \\
\mathrm{CR} & =\frac{0.018}{1.12} \\
\mathrm{CR} & =0.02
\end{aligned}
$$

The result of the consistency ratio is less than $10 \%$ or $<0.1$, then the value of the consistency ratio can be said that are consistent. 


\subsection{Analysis Of Assessing Alternative}

After getting the results from the priority table, then an alternative value score is carried out on the research title which given the value of the results of interviews from researchers given in the form of numerical values from 1 to 5 .

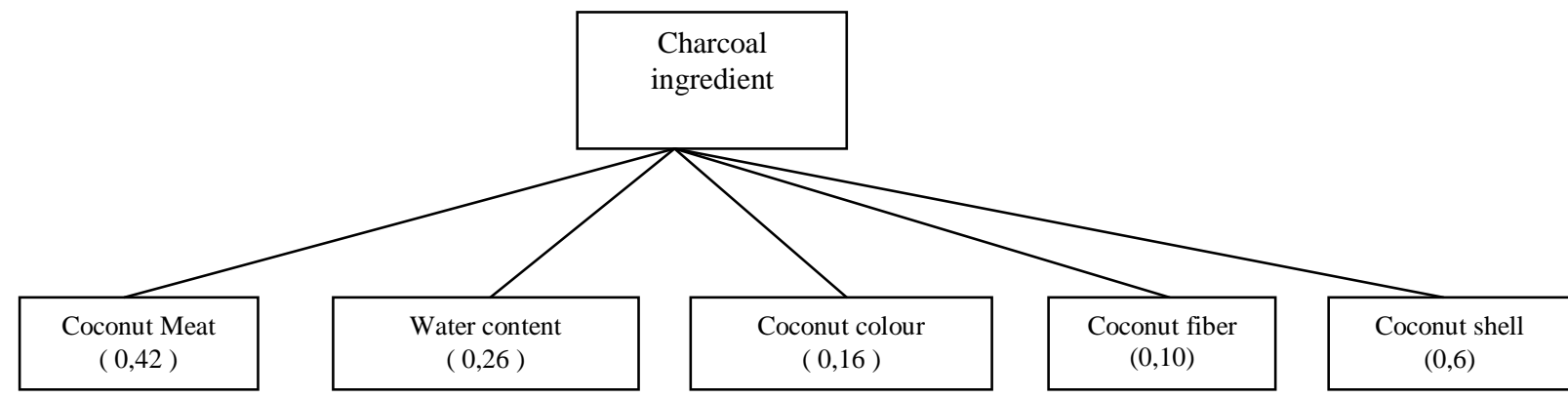

Figure 3 The Weights Based on Criteria.

\subsection{Alternative Analysis of the Results and Ranking}

The final step determines the best alternative by combining the results of the weighting of the criteria and alternative weighting based on the requirements that have done before, then do multiplication with each weighting criteria which obtained in the analysis.

After obtaining all Eigenvector values from each alternative for each criterion, the final result is to find the highest and lowest ranking of each alternative by multiplying the Eigenvector criteria values in table 4.9. With alternative eigenvector values created in a matrix table, with the following steps:

Alternative EV values $=($ Dk Alt $x$ DkKrt $)+($ Ka Alt x KaKrt $)+($ Wk Alt x WkKrt $)+($ Sk Alt x SkKrt $)+($ Bk Alt $x$ Bk Krt) and so on.

Table 4 Results of Alternative Analysis and Ranking

\begin{tabular}{|l|c|c|c|c|c|c|c|}
\hline \multicolumn{1}{|c|}{ title } & CM & CWC & CS & CF & SC & $\begin{array}{c}\text { Total of Eigen } \\
\text { alternating criteria }\end{array}$ & Priorities \\
\hline coocnut 1 & 0,590 & 0,602 & 0,592 & 0,658 & 0,584 & 0,600 & 1 \\
\hline coconut2 & 0,252 & 0,208 & 0,287 & 0,206 & 0,254 & 0,242 & 2 \\
\hline coconut3 & 0,120 & 0,120 & 0,088 & 0,101 & 0,119 & 0,113 & 3 \\
\hline coconut4 & 0,038 & 0,069 & 0,034 & 0,035 & 0,042 & 0,046 & 4 \\
\hline $\begin{array}{l}\text { Eigen Vektorresult } \\
\text { criteria }\end{array}$ & 0,419 & 0,263 & 0,160 & 0,097 & 0,062 & & \\
\hline
\end{tabular}

Weighting Priority Results:
1. Coconut $1=0,600$
2. Coconut $2=0.242$
3. Coconut $3=0.113$
4. Coconut $4=0.046$

Then from table 4.59. it can conclude that the highest ranking is the old coconut type $(0.600)$ and secondly by the koreang nature 2 (0.242), Coconut Type 3 is mudang coconut $(0.113)$ 
and the lowest rank is young coconut (0.046) as a consideration in the manufacture quality charcoal then analyzed, prioritized is "Old Coconut"

\section{Conclusions}

After getting the results from the priority table, then an alternative value weighting was carried out on the research title given the value of the results of interviews is 1 to 5 , it known that aspects of Coconut Meat, Coconut Water Content, Coconut Color, Coconut Fiber and Coconut Shell, is the aspect of carrying capacity and consideration of making quality of the Charcoal. The alternative owns the highest in the old coconut type (0.600) and secondly by the koreang coconut type $2(0.242)$, Coconut Type 3 is mudong coconut (0.113) and the lowest rank is young coconut (0.046) as a material for consideration in making quality charcoal then analyzed, prioritized is "Old Coconut". It expected that with the calculation of coconuts using AHP, later the briquette producer can increase its production yield.

\section{References}

[1] W. Sumarno, "Menjadi kerajinan tangan di nagari iv koto mudik," vol. 18, no. lidi, pp. 100-105, 2019..

[2] F.M Pratiwi,and P.K Sutara, Etnobotani Kelapa Di Wilayah Denpasar Dan Badung. J. Simbiosis (2013).

[3] T. Sari, W. Sumarni, and N. Widiarti, "pemanfaatan arang tempurung kelapa dan eceng gondok untuk menurunkan kadar bod dan cod", ICJS, vol. 3, no. 2, Aug. 2014.

[4] B. Pramudya, "Prospek Usaha Pembuatan Arang Tempurung Kelapa (Studi kasus UD. Beringin Jaya) Subandiyono , Bambang Pramudya dan Nora H. Pandjaitan," 1983.

[5] e. Lestari, "analisa sistem pendukung keputusan untuk proses kenaikan jabatan pada pt . X," vol. 1, no. 3, pp. 141-150, 2009.

[6] E.S Pasaribu, and Iskandar, "Karyawan Dengan Metode Analytical Hierarchy Process ( Ahp ) Studi Kasus Pada Pt. Selular Global Net Medan" Teknol. dan Sist. Inf. (2015).

[7] E. Darmanto et al., "Penerapan metode ahp ( analythic hierarchy process ) untuk," vol. 5, no. 1, pp. 75-82, 2014.

[8] F.P., Saputra, N Hidayat, and Furqon, M. T. "Penerapan Metode Fuzzy Analytical Hierarchy Process ( F-AHP ) Untuk Menentukan Besar Pinjaman Pada Koperasi" $J$. Pengemb. Teknol. Inf. dan Ilmu Komput. (2018).

[9] M. I. Siregar, D. Mallisza, W. Yahyan, and H. Hadi, "Sistem Pendukung Keputusan Penerimaan Pegawai pada Universitas Ekasakti Menggunakan Metode AHP", ijcs, vol. 8, no. 1, pp. 45-54, Apr. 2019.

[10] E. K. R. E Huizingh, and H. C.J .A Vrolijk, "comparison of verbal and numerical judgments in the analytic hierarchy process" Organ. Behav. Hum. Decis. Process. 1997

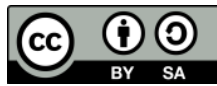

Digital Zone: Jurnal Teknologi Informasi dan Komunikasi is licensed under a Creative Commons Attribution International (CC BY-SA 4.0) 